\title{
A 7-YEAR SURVEY OF SUPERFICIAL AND CUTANEOUS MYCOSES IN A PUBLIC HOSPITAL IN NATAL, NORTHEAST BRAZIL
}

\author{
Nicácia Barbosa Calado ${ }^{1}$, Francisco Canindé de Sousa Júnior ${ }^{1}$, Mariana Guimarães Diniz ${ }^{1}$ Ana Cristina Santos \\ Fernandes ${ }^{1}$, Fernando José Ramos Cardoso ${ }^{2}$, Luiz Conrado Zaror ${ }^{3}$, Maria Ângela Fernandes Ferreira ${ }^{4}$, Eveline Pipolo \\ Milan $^{1^{*}}$
}

${ }^{1}$ Departamento de Infectologia, Universidade Federal do Rio Grande do Norte, Natal, RN, Brasil; ${ }^{2}$ Secretaria de Saúde Pública do Estado do Rio Grande do Norte, Natal, RN, Brasil; ${ }^{3}$ Instituto de Microbiologia Clínica, Universidad Austral de Chile, Valdivia, Chile. ${ }^{4}$ Departamento de Odontologia, Universidade Federal do Rio Grande do Norte, Natal, RN, Brasil.

Submitted: August 17, 2010; Returned to authors for corrections: January 10, 2011; Approved: May 30, 2011.

\begin{abstract}
In the present study, we determined the frequency of superficial and cutaneous mycoses and their etiologic agents during a 7-year period (2002-2008) in Natal, Brazil. A total of 1,717 specimens of skin, nail, and hair were collected from 1,382 patients with suspected mycoses lesions and were then subjected to direct microscopy and culture.
\end{abstract}

Key words: Cutaneous mycoses, Dermatophytes, Fungal infections, Yeasts, Superficial mycoses.

Superficial and cutaneous mycoses represent an important cause of morbidity for people worldwide, particularly in the tropics, and their incidence has increased in recent years to the extent that they are now a frequent cause of visits to dermatology outpatient departments (17). Various factors explain this fact, such as the use of closed-top footwear, tightfitting clothes, and the frequent practice of sports that exacerbate the increased heat and humidity, associated with a tropical climate, poor hygiene habits, playing in sand, and contact with domestic animals $(2,17)$.

In Natal, the frequency of superficial and cutaneous mycoses has not been well clarified. Thus, this study aimed to investigate the frequency of superficial and cutaneous mycoses and their etiological agents among patients examined at the Giselda Trigueiro Hospital, Natal, Brazil, between 2002 and 2008.

Between February 2002 and December 2008, a sectional study was performed to mycologically assess skin, hair, and nail lesions. The samples comprised 1,717 clinical specimens collected from 1,382 patients suspected of superficial and cutaneous mycoses visiting the Dermatology Service of Giselda Trigueiro Hospital. The skin, scalp, and nail scrapings were obtained with a sterilized scalpel and hair samples were removed with tweezers. The direct examination was performed immediately by visualizing the clinical material with $20 \%$ $\mathrm{KOH}$ plus Parker's blue permanent ink (2:1) under optical

*Corresponding Author. Mailing address: Departamento de Infectologia, Centro de Ciências da Saúde, UFRN, Rua Cônego Monte, 110, Quintas, 59037-170, Natal, RN, Brasil.; Fax: +55- 84- 3232 7948.; E-mail: eve@ufrnet.br 
microscope with 10X and 40X objective lenses.

Skin and scalp scales were cultivated in Sabouraud dextrose agar containing chloramphenicol and cycloheximide (Mycosel agar - BBL) and Lactrimel agar (Borelli medium). The nail scrapings were seeded in a tube containing Saubouraud agar $\left(\right.$ Difco $\left.^{\circledR}\right)$ with chloramphenicol $(200 \mathrm{mg} / \mathrm{L})$, in addition to the two mediums previously cited. After seeding, the material was incubated at $30^{\circ} \mathrm{C}$, for up to 21 days. Those samples in which direct examination revealed fungal elements suggestive of Malassezia spp. were not submitted to growing in a culture medium. Dermatophytes were identified by gross and microscopic morphology (microculturing) and biochemical criteria when necessary (7). The isolations of Candida species were identified by germ tube test and chlamydospore test.

The sample consisted of 1,382 patients, 848 females and 534 males, aged between 1 and 89 years, with a mean of 39.5 and a median of 40 years. A total of 1,717 suspected lesion samples were collected 883 (51\%) from skin, 732 (43\%) from nails, and $102(6 \%)$ from hair. Of these lesions, $695(40.5 \%)$ were considered positive for growing in a culture medium with negative or positive direct examination, as well as those in which direct examination revealed hyaline cells and fungal filaments, suggestive of Malassezia spp.

Yeasts were isolated in $59.9 \%$ of the positive lesions, followed by dermatophytes in $37.8 \%$ and Fusarium spp. in $2.3 \%$. The number and percentage distribution of the fungal agents according to anatomic site is shown in Table 1. In 148 $(21.3 \%)$ out of the 695 positive samples, Trichophyton rubrum was the most frequently isolated dermatophyte, followed by $T$. tonsurans in $10.8 \%$ of the cases. These results agree with those of a study performed in Fortaleza, Brazil, in which T. rubrum, T. tonsurans, and M. canis, in that order, were the most commonly isolated (2). T. tonsurans has shown itself to be well adapted to the high temperature and humidity of the North and Northeast regions of Brazil, which does not occur in the South and Southeast states, where the climate is dryer (2).

Table 1. Number and percentage distribution of superficial and cutaneous mycoses agents according to anatomic site, during the period 2003-2008 in a public hospital in Natal, Brazil.

\begin{tabular}{|c|c|c|c|c|c|c|c|c|}
\hline \multirow[b]{2}{*}{ Agents } & \multicolumn{7}{|c|}{ Anatomic site } & \multirow[b]{2}{*}{ Total } \\
\hline & SH & FT & $\mathbf{U L}$ & IC & $\mathbf{L L}$ & FN & TN & \\
\hline T. rubrum & $9(19.2)$ & $29(29.6)$ & $21(42.0)$ & $26(53.0)$ & $40(43.5)$ & $4(1.8)$ & $19(13.7)$ & $148(21.3)$ \\
\hline T. tonsurans & $20(42.6)$ & $21(21.4)$ & $8(16.0)$ & $8(16.3)$ & $9(9.8)$ & $2(0.9)$ & $7(5.0)$ & $75(10.8)$ \\
\hline T. mentagrophytes & $5(10.6)$ & $3(3.1)$ & - & $2(4.1)$ & $2(2.2)$ & $2(0.9)$ & $2(1.4)$ & $16(2.3)$ \\
\hline M. canis & $11(23.4)$ & $4(4.1)$ & - & $2(4.1)$ & $1(1.1)$ & - & - & $18(2.6)$ \\
\hline M. gypseum & $1(2.1)$ & - & - & - & $2(2.2)$ & - & - & $3(0.4)$ \\
\hline E. floccosum & - & - & $1(2.0)$ & - & $2(2.2)$ & - & - & $3(0.4)$ \\
\hline Fusarium spp. & - & - & - & - & $1(1.1)$ & $2(0.9)$ & $13(9.4)$ & $16(2.3)$ \\
\hline Malassezia spp. & - & $41(41.8)$ & $15(30.0)$ & $4(8.2)$ & $5(5.4)$ & - & - & $65(9.4)$ \\
\hline C. non-albicans & - & - & $2(4.0)$ & $2(4.1)$ & $15(16.3)$ & $127(57.7)$ & $77(55.4)$ & $223(32.1)$ \\
\hline C. albicans & - & - & $2(4.0)$ & $4(8.2)$ & $9(9.7)$ & $65(29.6)$ & $7(5.0)$ & $87(12.5)$ \\
\hline Trichosporon spp. & $1(2.1)$ & - & - & $1(2.0)$ & $6(6.5)$ & $15(6.8)$ & $14(10.1)$ & $37(5.3)$ \\
\hline Geotrichum spp. & - & - & - & - & - & $3(1.4)$ & - & $3(0.4)$ \\
\hline Hortaea werneckii & - & - & $1(2.0)$ & - & - & - & - & $1(0.1)$ \\
\hline Total & $47(100)$ & $98(100)$ & $50(100)$ & 49 (100) & $92(100)$ & $220(100)$ & $139(100)$ & $695(100)$ \\
\hline
\end{tabular}

SH: scalp and hair; FT: face and torso; UL: upper limbs; IC: inguinal-crural region; LL: lower limbs; FN: fingernails; TN: toenails. 
Studies performed in Brazil (8, 14, 16), Greece (9) and China (23) show that $M$. canis is the most prevalently isolated agent on the scalp and hair. However, in our study this agent was the second most commonly isolated, perhaps for not adapting well to the climactic conditions or because of the age group of the study population. In a study conducted in Fortaleza, Brazil, it was verified that $T$. tonsurans was the agent most frequently isolated in $54.4 \%$ of tinea capitis cases, corroborating the results of this study (3). It is important to consider that in this study the small number of patients under the age of 12 years may explain the reduced isolation of $M$. canis.

Of the yeasts observed, Candida non-albicans were identified in $32.1 \%$ of the lesions, followed by C. albicans (12.5\%), Malassezia spp. (9.4\%), Trichosporon spp. (5.3\%), and Geotrichum spp. (0.4\%).

Several studies have reported dermatophytes as the main etiological agent of onychomycosis, especially in temperate zones $(12,20)$. However, in this study, the percentage of dermatophytes isolated from nails was low. Candida spp. was the most commonly isolated fungus at this anatomic site. Similarly, Pontes et al. (19) in João Pessoa, Brazil, observed that the main fungi involved in onychomycosis were Candida species $(82 \%)$, followed by dermatophytes (13.4\%). Brilhante et al. (4) also reported that the etiological agents most frequently found in cases of onychomycosis in Ceará (Northeast Brazil) were Candida species (75.42\%), followed by dermatophytes (12.99\%) and Fusarium spp. (8.19\%). In our study, the dermatophytes most commonly isolated in nail were T. rubrum, T. tonsurans, and T. mentagrophytes. The dermatophytes were the most commonly isolated in toenail, accounting for $20.0 \%$ more positive cultures than in fingernail $(3.6 \%)$.

In Brazil, several studies have shown that Fusarium spp. is the most common nondermatophyte mould causing onychomycosis and its spread has increased in recent years (4, $11,22)$. In Natal, we have previously reported eight cases of cutaneous lesions caused by Fusarium spp. in immunocompetent patients (5). In the present study, we report 15 cases of Fusarium ssp. onychomycosis and 1 case of Fusarium spp. interdigital intertrigo. Out of these 16 patients, $13(81.3 \%)$ were females ranging in age from 13 to 66 . Similarly, López et al. (13) reports that the incidence of onychomycosis caused by this fungus is greater in women than it is in men.

In this study, we observed three cases of onychomycosis caused by Geotrichum spp. These three cases showed direct positive mycologic examination and the growth of the same agent in pure cultures in at least three tubes of Sabouraud dextrose agar. Similar to our study, Souza et al. (21) reported 22 cases of Geotrichum candidum onychomycosis in Maringa, Brazil.

Malassezia spp. yeasts are part of the microbiota of human skin. Under certain predisposing conditions, they produce pityriasis versicolor, which is more frequently found in regions where temperature and humidity are elevated (6). In this study, Malassezia spp. was found in $41.8 \%$ of face and torso lesions and it was the second most commonly observed agent in upper limb lesions, representing $30.0 \%$ of these cases. These results corroborate those of Arenas et al. (1), who report that the majority of pityriasis versicolor lesions occur on the torso and arm.

Of the lesions in which Trichosporon spp. was identified, one was a case of white piedra in a 2 year-old female patient with a history of small, white concretions attached to hair for the previous 4 months. Estrada et al. (10) also communicated a case of white piedra in Culiacán, Mexico in a 3 year-old female patient with white-yellowish nodules on the scalp hair. In addition, Trichosporon spp. was isolated from skin lesions and onychomycosis.

The black yeast Hortaea werneckii was isolated from a case of tinea nigra in the right palm of a 10-year-old female patient who presented with an asymptomatic lesion one year before. In a study performed in Venezuela, 10 cases were 
reported in female patients with lesions localized mainly on the palmar or plantar region (18). In a study carried out by Mattêde et al. (15), H. werneckii was isolated in ocean beach sand, but considering the low incidence of this infection, in contrast to the high number of individuals who frequent the beaches in our region, this is not likely the main form of contagion. The instability of the local immunity and/or skin lesion may favor $H$. werneckii infection.

In conclusion, our study showed that the most common isolated agent of superficial and cutaneous mycoses in Natal was Candida spp. and T. rubrum was the second most prevalent species. Fingernail onychomycosis caused by Candida ssp. was the most frequent dermatomycoses. These results showed that there is a high frequency of yeasts as etiologic agents of cutaneous mycoses in our city.

\section{REFERENCES}

1. Arenas, R.; Isa, R.I.; Cruz, A.C. (2001). Pitiriasis versicolor en Santo Domingo, República Dominicana. Datos morfológicos de Malassezia spp. in vivo en 100 casos. Rev. Iberoamer. Micol. 18(1), 29-32.

2. Brilhante, R.S.; Paixão, G.C.; Salvino, L.K.; Diógenes, M.J.; Bandeira, S.P.; Rocha, M.F.; dos Santos, J.B.; Sidrim, J.J. (2000). Epidemiologia e ecologia das dermatofitoses na cidade de Fortaleza: o Trichophyton tonsurans como importante patógeno emergente da Tinea capitis. Rev. Soc. Bras. Med. Trop. 33(5), 417-425.

3. Brilhante, R.S.N.; Cordeiro, R.A.; Rocha, M.F.G.; Monteiro, A.J.; Meireles, T.E.F.; Sidrim, J.J.C. (2004). Tinea capitis in a dermatology center in the city of Fortaleza, Brazil: the role of Trichophyton tonsurans. Int. J. Dermatol. 43(8), 575-579.

4. Brilhante, R.S.; Cordeiro, R.A.; Medrano, D.J.; Rocha, M.F.; Monteiro, A.J.; Cavalcante, C.S.; Meireles, T.E.; Sidrim, J.J. (2005). Onychomycosis in Ceará (Northeast Brazil): epidemiological and laboratory aspects. Mem. Inst. Oswaldo Cruz. 100(2), 131-135.

5. Calado, N.B.; Sousa Jr, F.; Gomes, N.O.; Cardoso, F.R.; Zaror, L.C.; Milan, E.P. (2006). Fusarium nail and skin infection: a report of eight cases from Natal, Brazil. Mycopathologia. 161(1), 27-31.

6. Crespo-Erchiga, V.; Florencio, V.D. (2006). Malassezia yeasts and pityriasis versicolor. Curr. Opin. Infect. Dis. 19(2), 139-147.

7. De Hoog, G.S.; Guarro, J.; Gené, J.; Figueiras, M.J. (2000). Atlas of clinical fungi. $2^{\text {nd }}$ ed. Utrecht/Reus: CBS/Universitat Rovira i Virgili.

8. Dias, T.; Fernandes, O.F.L.; Soares, A.J.; Passos, X.S.; Costa, M.; Souza, L.K..H; Silva, M.R.R. (2003) Tinha do couro cabeludo em crianças de
Goiânia, Brasil. Rev. Soc. Bras. Med. Trop. 36(6),653-655.

9. Eremondi, T.K.; Panagiotidou, D.D.; Tsatsou, O.M.; Minas, A. (2005). Epidemiology of dermatomycoses in children living in Northern Greece 1996-2000. Mycoses. 48(1), 11-16.

10. Estrada, V.F.M.; Carrizales, E.E.D.; Castro, J.L.G.; Acuña, J.R.T. (2009). Piedra blanca em uma paciente pediátrica: reporte de um caso. Rev. Iberoam. Micol. 26(4), 252-254.

11. Godoy-Martinez, P.; Nunes, F.G.; Tomimori-Yamashita, J.; Urrutia, M.; Zaror, L.; Silva, V.; Fischman, O. (2009). Onychomycosis in São Paulo, Brazil. Mycopathologia. 168(3), 111-116.

12. Järv, H.; Naaber, P.; Kaur, S.; Eisen, M.; Silm, H. (2004). Toenail onychomycosis in Estonia. Mycoses. 47(1), 57-61.

13. López, N.C.; Casas, C.; Sopo, L.; Rojas, A.; Del Portillo, P.; Cepero de García, M.C.; Restrepo, S. (2009). Fusarium species detected in onychomycosis in Colombia. Mycoses. 52(4), 350-356.

14. Marques, S.A.; Camargo, R.M.P.; Fares, A.H.G.; Takashi, R.M.; Stolf, H.O. (2005). Tinea capitis: epidemiologia e ecologia dos casos observados entre 1983 e 2003 na Faculdade de Medicina de Botucatu, Estado de São Paulo, Brasil. An. Bras. Dermatol. 80(6), 597-602.

15. Mattêde, M.G.S.; Nascimento, F.F.; Mattêde, A.F.; Palhano Jr, L. (1986). Flora micótica das praias oceânicas poluídas e não poluídas em clima de verão. Cien. Cult. 38(4), 664-671.

16. Moraes, M.S.; Godoy-Martínez, P.; Alchorne, M.M.; Boatto, H.F.; Fischman, O. (2006). Incidence of Tinea capitis in São Paulo, Brazil. Mycopathologia.162(2), 91-95.

17. Pelegrini, A.; Takahashi, J.P.; Pereira, C.Q.; Pessoni, R.B.; Souza, M.C. (2009). Incidence of dermatophytosis in a public hospital of São Bernardo do Campo, São Paulo State, Brazil. Rev. Iberoam. Micol. 26(2), 118-120.

18. Perez, C.; Colella, M.T.; Olaizola, C.; Capriles, C.H.; Magaldi, S.; MataEssayag, S. (2005). Tinea nigra: report of twelve cases in Venezuela. Mycopathologia. 160(3), 235-238.

19. Pontes, Z.B.; Lima, E.O.; Oliveira, N.M.; Dos Santos, J.P.; Ramos, A.L.; Carvalho, M.F. (2002). Onychomycosis in João Pessoa city, Brazil. Rev. Argent. Microbiol. 34(2), 95-99.

20. Romano, C.; Gianni, C.; Difonzo, E.M. (2005). Retrospective study of onychomycosis in Italy: 1985-2000. Mycoses. 48(1), 42-44.

21. Souza, E.A.F.; Almeida, L.M.M.; Guilhermetti, E.; Mota, V.A.; Rossi, R.M.; Svidzinski, T.I.E. (2007). Freqüência de onicomicoses por leveduras em Maringá, Paraná, Brasil. An. Bras. Dermatol. 82(2), 151156.

22. Souza, L.K.; Fernandes, O.F.; Passos, X.S.; Costa, C.R., Lemos, J.A.; Silva, M.R. (2010). Epidemiological and mycological data of onychomycosis in Goiania, Brazil. Mycoses. 53(1), 68-71.

23. Zhu, M.; Li, L.; Wang, J.; Zhang, C.; Kang, K.; Zhang, Q. (2010). Tinea capitis in Southeastern China: A 16-Year Survey. Mycopathologia. $169(4), 235-239$. 